\title{
Blood Biochemical Profile of Swarnadhara Grower Parents as Influenced by Different Levels of Energy and Protein in the Diet
}

\author{
N. Suma ${ }^{1}$ *, B. S. Venkatarami Reddy ${ }^{1}$, S. Naveen Kumar ${ }^{2}$, K. P. Chethan ${ }^{3}$, \\ G.U. Manju ${ }^{3}$ and J. Adarsh ${ }^{1}$
}

${ }^{1}$ Department of Animal Nutrition, Veterinary College, KVAFSU, Bengaluru 560 024, India

${ }^{2}$ Department of Animal Genetics and Breeding, Veterinary College, KVAFSU, Bengaluru 560 024, India

${ }^{3}$ Department of Animal Nutrition, Veterinary College, KVAFSU, Hassan, India

*Corresponding author

\section{A B S T R A C T}

\begin{tabular}{|c|}
\hline Keywords \\
\hline $\begin{array}{l}\text { Blood mineral } \\
\text { profile, Deep litter } \\
\text { system, Energy, } \\
\text { Grower stage, } \\
\text { Protein } \\
\text { Swarnadhara }\end{array}$ \\
\hline Article Info \\
\hline $\begin{array}{l}\text { Accepted: } \\
\text { 05 February } 2020 \\
\text { Available Online: } \\
10 \text { March } 2020\end{array}$ \\
\hline
\end{tabular}

A feeding trial was conducted in female parent stock of Swarnadhara for 8 weeks during grower stage. Test diets were formulated at variable levels of energy (2500 / $2400 \mathrm{kcal} \mathrm{ME} \mathrm{/} \mathrm{kg)} \mathrm{and} \mathrm{protein}(16 / 15 \% \mathrm{CP})$ to form 4 treatments (High Energy/High Protein- $\mathrm{T}_{1}$; High Energy/Low Protein $\mathrm{T}_{2}$; Low Energy/High Protein- $\mathrm{T}_{3}$ and Low Energy/Low Protein-T $\left.\mathrm{T}_{4}\right) .384$ grower birds $(13-20$ weeks age) were divided into 32 replicates of 12 birds each to offer four diets randomly to 8 replicate groups under deep litter system. A linear increase in calcium concentration over all from beginning to the end of the experiment in all the dietary groups was observed. But, the pooled mean serum calcium $(\mathrm{P} \geq 0.05)$ values were $14.8,14.6,14.7$ and $14.8 \mathrm{mg} / \mathrm{dl}$ in groups $\mathrm{T}_{1}, \mathrm{~T}_{2}, \mathrm{~T}_{3}$ and $\mathrm{T}_{4}$, respectively. However, the pooled mean plasma inorganic phosphorus values ranged non-significantly $(\mathrm{P} \geq 0.05)$ from 5.9 (T2) to $6.3 \mathrm{mg} / \mathrm{dl}\left(\mathrm{T}_{3}\right)$. The varied results indicate a gradual increase in concentration of both the minerals as age advanced. Chosen energy as well as protein levels of Swarnadhra birds during grower stage have showed no adverse effect with respect to blood mineral profile.

\section{Introduction}

Poultry and poultry products owe for the better protein to human beings economically at lower price. Global meat production has been increased from 125 million MT in 2018 to 128.4 million MT in 2019 showing just 3
$\%$ growth. However, global egg production of about 80.1 million MT in 2017 witnessed an increase of nearly $25 \%$ from last 10 years. Whereas, India stands $3^{\text {rd }}$ in both poultry meat and egg production after China and USA with production of about 4.85 million MT of meat and 88.14 billion eggs and making proud as 
one among the world's largest producers (Poultry Trends, 2019).

Though the modern intensive poultry production has achieved dramatic gains in the efficient and economical production of high quality and safe chicken meat, eggs and poultry by-products, about 90 per cent of families engaged in backyard poultry keep an average of 10 to 15 adult low producing desi fowls maintained by women.

Vast majority of people in rural areas in general and harsh environments in particular have a strong liking for colored birds since they escape from the predators being camouflaged by their color (Krishna Rao, 2002; Veeranna, 2019).

Scavenging / free range / semi intensive poultry production is having many constraints which need proper appraisal for the success are lack of improved germplasm suitable for rural conditions, supplementation of small quantity of balanced feed to the birds besides natural resources as well as lack of technical know-how (Johri and Shrivastava 2005; Singh, 2005). In this direction, Swarnadhara, is one among such strains to fulfill economically weaker people desire for better production traits.

Nutrient requirements for Swarnadhara birds may differ from that of extensively documented Leghorn type breeds despite their high survivability under scavenging conditions. Hence, breeder stock should be provided with balanced ration to exploit its genetic potential as well as to multiply a large number suitable for rural conditions.

In this direction, a concise study to know the effect of varied levels of energy as well as protein in ration of Swarnadhara grower parents on blood parameters was planned.

\section{Materials and Methods}

Parent stock of Swarnadhara strain; akin to country fowl which was developed for rural scavenging conditions were selected for study in grower stage.

\section{Experimental diets}

Grower mash diets of $\mathrm{T}_{1}$ to $\mathrm{T}_{4}$ were formulated using yellow maize, deoiled rice bran, soybean meal, sunflower extractions, salt, mineral mixture and additives to interrelate two levels of energy with two levels of protein. Diet description of the experiment is given in Table 1.

The dietary details regarding ingredient composition is being given in Table 2 and all the diets formulated were subjected for analysis according to standard procedures (AOAC, 2005). Whereas, the calculated nutrient profile of the different diets is detailed in Table 3.

\section{Experimental birds' randomization}

A total number of 384 Swarnadhara female parent stock of about 9 weeks age were selected. And were stabilized for 21 days being fed with a restricted conventional practical grower mash diet. At the birds age of 12 weeks, all were divided into 32 groups of 12 birds each and each of the previously mentioned 4 diets was offered randomly to 8 groups to make replicates per treatment. Experiment was carried out by a completely randomized design.

All the birds were housed under deep litter system provided with paddy husk as the litter material. From 13 to 20 weeks of experimental period, feed restriction programme was followed to maintain the ideal body weight of the breeder flock. All the pens were provided with a tubular type of 
feeder and a continuous channel type of waterer on both sides of the house for clean and fresh water. By and large care was taken to distribute replications uniformly in all treatments.

\section{Experimental care during trial}

Beak trimming (upper $1 / 3^{\text {rd }}$ ) was done using electrical debeaker to prevent cannibalism for all the experimental birds at the age of $10^{\text {th }}$ week and during $11^{\text {th }}$ week, they were dewormed using levamisole (@ 13 mg/kg BW) through feed. Subsequently, all the birds were vaccinated against New Castle Disease using live vaccine through subcutaneous route during $12^{\text {th }}$ week. That apart, all the birds were maintained under uniform standard managemental conditions including lighting programme, preventive or therapeutic disease control schedule, feeding frequency, watering methods and other routine bio-security aspects. This experiment lasted for 56 days which was conveniently divided into four 14day interval periods for sorting arrived data.

\section{Blood biochemical profile}

Two birds were randomly selected from each replication at the start of the experiment (i.e., $12^{\text {th }}$ week of birds' age) and $2 \mathrm{ml}$ of blood was collected from its wing vein. $1 \mathrm{ml}$ of blood collected from each bird was transferred into a clean, sterilized and labeled test tube containing EDTA for plasma separation and other $1 \mathrm{ml}$ of the blood collected was transferred into a clean, sterilized and labeled test tube for serum separation. The contents of EDTA containing test tubes were centrifuged and the supernatant plasma was collected in a vial which was clean, sterilized and labeled. The other test tube without EDTA was held in a slanting position for serum separation as per the standard procedures (Calneck et al., 1992) and the clear non-haemolysed serum was then transferred into a vial which was clean, sterilized and labeled. Later, separated serum and plasma samples were stored at $-20^{\circ} \mathrm{C}$ for further estimation of calcium and inorganic phosphorus, respectively. Further, the same birds were bled to collect the blood and separated plasma as well as serum at subsequent 28-day intervals.

The inorganic phosphorus and calcium contents of plasma and serum samples, respectively, were analyzed using autoanalyzer (BT-224 photometer) as described by commercial supplier (M/s. Span Diagnostics).

\section{Statistical analysis}

The data pertaining to blood mineral profile obtained during the grower experimental trial were analyzed in completely randomized design according to the procedures described by Snedecor and Cochran (1989).

\section{Results and Discussion}

\section{Experimental diets composition}

The proximate composition including that of calcium and phosphorus of experimental grower diets compounded on different occasions of the 56-day experimental period analyzed is given in Table 4.

The dry matter (DM) content estimated for experimental diets ranged from $90.54\left(\mathrm{~T}_{4}\right)$ to $91.23\left(\mathrm{~T}_{1}\right)$ per cent while that of analyzed crude protein (CP) content was 16.42, 15.02, 15.96 and 15.23 per cent, respectively in $T_{1}$, $\mathrm{T}_{2}, \mathrm{~T}_{3}$ and $\mathrm{T}_{4}$ diets in that order. The ether extract (EE), crude fiber (CF), total ash (TA) and nitrogen free extractives (NFE) of experimental diets were ranging from 1.98 $\left(\mathrm{T}_{4}\right)$ to $2.33\left(\mathrm{~T}_{2}\right) ; 10.12\left(\mathrm{~T}_{1}\right)$ to $12.11\left(\mathrm{~T}_{4}\right)$; $8.32\left(\mathrm{~T}_{3}\right)$ to $9.41\left(\mathrm{~T}_{4}\right)$ and $61.27\left(\mathrm{~T}_{4}\right)$ to 62.97 $\left(\mathrm{T}_{2}\right)$ per cent, respectively. 
The mineral composition analyzed for calcium and phosphorus of the test diets were ranged from $1.26\left(\mathrm{~T}_{2}\right)$ to $1.31\left(\mathrm{~T}_{1}\right)$ and 1.14 $\left(\mathrm{T}_{1}\right)$ to $1.21\left(\mathrm{~T}_{2}\right)$, respectively. Whereas, the calculated metabolizable energy (ME) values were found to be $2534\left(\mathrm{~T}_{1}\right), 2524\left(\mathrm{~T}_{2}\right), 2448$ $\left(\mathrm{T}_{3}\right)$ and $2441\left(\mathrm{~T}_{4}\right) \mathrm{kcal} / \mathrm{kg}$.

All the laboratory analyzed values were fairly in close agreement with the calculated values, based on which the formulation of diets was indeed attempted. Noticed an incremental level of crude fiber in low densed diets compared to their counterparts was obviously due to gradual increase in deoiled rice bran as well as sunflower extractions on one hand and gradual decrease in maize as well as soybean meal on the other hand. Contrarily, the estimated calcium as well as the total phosphorus content of all the diets was slightly higher than the calculated ones.

The protein levels chosen in the $T_{2}$ and $T_{4}$ test diets of the present study were close to the value as recommended by [9]. However, the other two diets i.e., $\mathrm{T}_{1}$ and $\mathrm{T}_{3}$ were selected with slightly higher protein values to see the counter effect, if any. Contrarily, the metabolizable energy levels were much lower than the values recommended by Reddy and Rajendiran (2002).

\section{Blood mineral profile}

The blood mineral profile viz. serum calcium and plasma inorganic phosphorus contents of birds under different treatments at every 28day interval for three consecutive times as well as pooled mean values of 56-day experimental period are presented in Table 5 and Table 6 , respectively.

The mentioned blood mineral profiles under different treatments were found to be statistically $(\mathrm{P} \geq 0.05)$ similar throughout the experiment.

The non-significant $(\mathrm{P} \geq 0.05)$ mean values of serum calcium at beginning $\left(1^{\text {st }}\right.$ day), $28^{\text {th }}$ day and $56^{\text {th }}$ days of the trial ranged respectively, from $14.1\left(\mathrm{~T}_{2}\right)$ to $14.3\left(\mathrm{~T}_{4}\right)$; from $14.7\left(\mathrm{~T}_{2}\right)$ to $15.0\left(\mathrm{~T}_{4}\right)$ and from $15.0\left(\mathrm{~T}_{2}\right)$ to $15.5\left(\mathrm{~T}_{1}\right)$ $\mathrm{mg} / \mathrm{dl}$. Lower serum calcium values were recorded in high energy low protein group $\left(\mathrm{T}_{2}\right)$ throughout the experiment while the low energy low protein group $\left(\mathrm{T}_{4}\right)$ revealed higher values on initial stages but however, on $56^{\text {th }}$ day the highest value was seen in high energy high protein fed group $\left(\mathrm{T}_{1}\right)$. Overall, there was a linear increase in calcium concentration over all from beginning to the end of the experiment in all the dietary groups. The pooled mean $(\mathrm{P} \geq 0.05)$ values were 14.8 , 14.6, 14.7 and $14.8 \mathrm{mg} / \mathrm{dl}$ in groups $\mathrm{T}_{1}, \mathrm{~T}_{2}, \mathrm{~T}_{3}$ and $\mathrm{T}_{4}$, respectively.

Table.1 Description of dietary levels of energy and protein for different experimental diets

\begin{tabular}{|c|c|c|c|}
\hline & Treatment & $\begin{array}{c}\text { Metabolizable Energy } \\
\text { (kcal/kg) }\end{array}$ & Crude Protein (\%) \\
\hline No. & Description & 2500 & $\mathbf{1 6}$ \\
\hline $\mathbf{T}_{\mathbf{1}}$ & High Energy High Protein & 2500 & $\mathbf{1 5}$ \\
\hline $\mathbf{T}_{\mathbf{2}}$ & High Energy Low Protein & 2400 & $\mathbf{1 6}$ \\
\hline $\mathbf{T}_{\mathbf{3}}$ & Low Energy High Protein & $\mathbf{2 4 0 0}$ & $\mathbf{1 5}$ \\
\hline $\mathbf{T}_{\mathbf{4}}$ & Low Energy Low Protein & & \\
\hline
\end{tabular}


Table. 2 Composition of different ingredients of experimental diets compounded during feeding trial

\begin{tabular}{|c|c|c|c|c|}
\hline Ingredient, kg & $\mathbf{T}_{1}$ & $\mathbf{T}_{2}$ & $\mathbf{T}_{3}$ & $\mathbf{T}_{4}$ \\
\hline Maize & 444 & 440 & 374 & 373 \\
\hline De-oiled rice bran & 270 & 305 & 330 & 350 \\
\hline Soybean meal & 60 & 28 & 25 & 0 \\
\hline Sunflower extractions & 188 & 189 & 233 & 239 \\
\hline Salt & 3 & 3 & 3 & 3 \\
\hline Mineral mixture ${ }^{1}$ & 35 & 35 & 35 & 35 \\
\hline Total & 1000 & 1000 & 1000 & 1000 \\
\hline \multicolumn{5}{|l|}{ Additives, g/ton } \\
\hline $\mathbf{A B}_{2} \mathbf{D}_{3} \mathbf{K}^{2}$ & 150 & 150 & 150 & 150 \\
\hline B complex ${ }^{3}$ & 200 & 200 & 200 & 200 \\
\hline DL-Methionine ${ }^{4}$ & 500 & 500 & 500 & 500 \\
\hline Coxistat $^{5}$ & 750 & 750 & 750 & 750 \\
\hline Albac $^{6}$ & 300 & 300 & 300 & 300 \\
\hline
\end{tabular}

1 Mineral mixture contained: Moisture $-3 \%, \mathrm{Ca}-32 \%, \mathrm{P}-9 \%, \mathrm{Mn}-0.27 \%, \mathrm{Zn}-0.26 \%, \mathrm{I}-0.01 \%, \mathrm{Cu}-$ $0.01 \%, \mathrm{Fe}-0.10 \%, \mathrm{Fl}-0.03 \%$ (Max).

2 Each gram contained: Vitamin A - 82,500 IU, Vitamin $\mathrm{B}_{2}-50 \mathrm{mg}$, Vitamin $\mathrm{D}_{3}-12,000 \mathrm{IU}$, Vitamin $\mathrm{K}-10 \mathrm{mg}$, Organic Nutritive Carrier - Q.S.

3 Each gram contained: Vitamin $\mathrm{B}_{1}-4 \mathrm{mg}$, Vitamin $\mathrm{B}_{6}-8 \mathrm{mg}$, Vitamin $\mathrm{B}_{12}-40 \mu \mathrm{g}$, Vitamin $\mathrm{E}-40 \mathrm{mg}$, Calciumd-pantothenate - $40 \mathrm{mg}$, Niacin - $60 \mathrm{mg}$, Organic Nutritive Carrier - Q.S.

4 Each gram contained: DL-Methionine - $980 \mathrm{mg}$.

Anticoccidial contained Maduramycin Ammonium - 1\%

${ }^{6}$ Antibiotic growth promoter contained Zinc Bacitracin - 15\% 
Table.3 Nutrient profile of experimental diets compounded during feeding trial

\begin{tabular}{|l|c|c|c|c|}
\hline Nutrient & $\mathbf{T}_{\mathbf{1}}$ & $\mathbf{T}_{\mathbf{2}}$ & $\mathbf{T}_{\mathbf{3}}$ & $\mathbf{T}_{\mathbf{4}}$ \\
\hline ME kcal/kg & 2534 & 2524 & 2448 & 2441 \\
\hline CP \% & 16.22 & 15.36 & 16.27 & 15.65 \\
\hline EE\% & 2.08 & 2.08 & 1.92 & 1.92 \\
\hline LA \% & 1.14 & 1.12 & 1.02 & 1.01 \\
\hline CF \% & 9.71 & 9.98 & 11.22 & 11.46 \\
\hline Ca \% & 1.20 & 1.19 & 1.20 & 1.19 \\
\hline TP \% & 1.06 & 1.09 & 1.14 & 1.16 \\
\hline Pav \% & 0.45 & 0.44 & 0.44 & 0.44 \\
\hline Na \% & 0.16 & 0.16 & 0.16 & 0.16 \\
\hline Cl \% & 0.24 & 0.24 & 0.24 & 0.16 \\
\hline K \% & 0.76 & 0.74 & 0.78 & 0.76 \\
\hline Mg mg & 0.40 & 0.41 & 0.45 & 0.47 \\
\hline S \% & 0.17 & 0.16 & 0.17 & 0.17 \\
\hline Fe ppm & 246 & 247 & 228 & 229 \\
\hline I ppm & 3.50 & 3.50 & 3.50 & 3.50 \\
\hline Cu ppm & 7.07 & 6.48 & 6.29 & 5.81 \\
\hline Mn ppm & 102 & 101 & 101 & 101 \\
\hline Zn ppm & 105 & 105 & 105 & 105 \\
\hline Se ppm & 0.02 & 0.02 & 0.01 & 0.01 \\
\hline Met \% & 0.33 & 0.32 & 0.34 & 0.33 \\
\hline Met + Cyst\% & 0.55 & 0.53 & 0.56 & 0.55 \\
\hline Lys \% & 0.62 & 0.56 & 0.60 & 0.56 \\
\hline Arg \% & 1.06 & 1.00 & 1.08 & 1.04 \\
\hline Ratios & & & & \\
\hline C/P & 156 & 164 & 150 & 156 \\
\hline Ca/Pav & 2.70 & 2.70 & 2.71 & 2.71 \\
\hline Arg/Lys & 1.71 & 1.78 & 1.81 & 1.88 \\
\hline & & & & \\
\hline
\end{tabular}


Table.4 Chemical composition of analysed experimental diets compounded during grower phase of the experiment

\begin{tabular}{|c|c|c|c|c|c|c|c|c|c|c|}
\hline \multicolumn{2}{|c|}{ Treatment } & \multicolumn{5}{|c|}{ Proximate Composition (\%) } & \multicolumn{2}{|c|}{$\begin{array}{c}\text { Minerals } \\
(\%)\end{array}$} & $\begin{array}{l}\mathbf{M E}^{\mathbf{2}} \\
\text { (kcal } \\
\text { /kg) }\end{array}$ \\
\hline No. & Description & $\begin{array}{c}\text { Dry } \\
\text { matter }\end{array}$ & $\begin{array}{c}\text { Crude } \\
\text { Protein }\end{array}$ & $\begin{array}{c}\text { Ether } \\
\text { Extract }\end{array}$ & $\begin{array}{c}\text { Crude } \\
\text { Fiber }\end{array}$ & $\begin{array}{c}\text { Total } \\
\text { Ash }\end{array}$ & NFE & Ca & P & \\
\hline $\mathbf{T}_{\mathbf{1}}$ & $\begin{array}{l}\text { High Energy } \\
\text { High Protein }\end{array}$ & 91.23 & 16.42 & 2.28 & 10.12 & 8.84 & 62.34 & 1.31 & 1.14 & 2534 \\
\hline $\mathbf{T}_{\mathbf{2}}$ & $\begin{array}{l}\text { High Energy } \\
\text { Low Protein }\end{array}$ & 91.14 & 15.02 & 2.33 & 10.56 & 9.12 & 62.97 & 1.26 & 1.21 & 2524 \\
\hline $\mathbf{T}_{3}$ & $\begin{array}{l}\text { Low Energy } \\
\text { High Protein }\end{array}$ & 90.79 & 15.96 & 2.01 & 10.87 & 8.32 & 62.84 & 1.27 & 1.15 & 2448 \\
\hline $\mathbf{T}_{\mathbf{4}}$ & $\begin{array}{c}\text { Low Energy } \\
\text { Low Protein }\end{array}$ & 90.54 & 15.23 & 1.98 & 12.11 & 9.41 & 61.27 & 1.30 & 1.19 & 2441 \\
\hline
\end{tabular}

${ }^{1}$ Average values of samples on 4 occasions.

${ }^{2}$ Calculated value

Table.5 Serum calcium profile of experimental birds fed different diets during different time intervals of grower trial

\begin{tabular}{|c|c|c|c|c|c|c|c|c|c|c|c|c|}
\hline \multicolumn{2}{|c|}{ Treatment } & \multicolumn{11}{|c|}{ Serum Ca (mg/dl) ${ }^{\text {NS }}$} \\
\hline No. & Description & \multicolumn{2}{|c|}{$1^{\text {st }}$ Day } & \multicolumn{3}{|c|}{$28^{\text {th }}$ Day } & \multicolumn{3}{|c|}{$56^{\text {th }}$ Day } & \multicolumn{3}{|c|}{ Mean } \\
\hline $\mathbf{T}_{1}$ & $\begin{array}{l}\text { High Energy } \\
\text { High Protein }\end{array}$ & 14.2 & \pm 0.25 & 14.8 & \pm & 0.45 & 15.5 & \pm & 0.19 & 14.8 & \pm & 0.18 \\
\hline $\mathbf{T}_{2}$ & $\begin{array}{l}\text { High Energy } \\
\text { Low Protein }\end{array}$ & 14.1 & \pm 0.39 & 14.7 & \pm & 0.33 & 15.0 & \pm & 0.48 & 14.6 & \pm & 0.23 \\
\hline $\mathbf{T}_{3}$ & $\begin{array}{l}\text { Low Energy } \\
\text { High Protein }\end{array}$ & 14.3 & \pm 0.33 & 14.7 & \pm & 0.46 & 15.2 & \pm & 0.45 & 14.7 & \pm & 0.26 \\
\hline $\mathbf{T}_{4}$ & $\begin{array}{l}\text { Low Energy } \\
\text { Low Protein }\end{array}$ & 14.3 & \pm 0.37 & 15.0 & \pm & 0.41 & 15.2 & \pm & 0.38 & 14.8 & \pm & 0.21 \\
\hline & CD & & - & & - & & & - & & & - & \\
\hline & F-value & & .09 & & 0.14 & & & 0.32 & & & 0.24 & \\
\hline
\end{tabular}


Table.6 Plasma inorganic phosphorous profile of experimental birds fed different diets during different time intervals of grower trial

\begin{tabular}{|c|c|c|c|c|c|c|c|c|c|c|c|c|c|}
\hline \multicolumn{2}{|c|}{ Treatment } & \multicolumn{12}{|c|}{ Plasma inorganic $P(\mathrm{mg} / \mathrm{dl}){ }^{\mathrm{NS}}$} \\
\hline No. & Description & \multicolumn{3}{|c|}{$1^{\text {st }}$ Day } & \multicolumn{3}{|c|}{$28^{\text {th }}$ Day } & \multicolumn{3}{|c|}{$56^{\text {th }}$ Day } & \multicolumn{3}{|c|}{ Mean } \\
\hline $\mathbf{T}_{1}$ & $\begin{array}{l}\text { High Energy } \\
\text { High Protein }\end{array}$ & 5.8 & \pm & 0.12 & 5.9 & \pm & 0.22 & 6.7 & \pm & 0.27 & 6.1 & \pm & 0.15 \\
\hline $\mathbf{T}_{2}$ & $\begin{array}{l}\text { High Energy } \\
\text { Low Protein }\end{array}$ & 5.6 & \pm & 0.25 & 6.0 & \pm & 0.19 & 6.1 & \pm & 0.31 & 5.9 & \pm & 0.17 \\
\hline $\mathbf{T}_{\mathbf{3}}$ & $\begin{array}{l}\text { Low Energy } \\
\text { High Protein }\end{array}$ & 5.7 & \pm & 0.18 & 6.0 & \pm & 0.21 & 7.0 & \pm & 0.32 & 6.3 & \pm & 0.13 \\
\hline $\mathbf{T}_{4}$ & $\begin{array}{l}\text { Low Energy } \\
\text { Low Protein }\end{array}$ & 5.9 & \pm & 0.09 & 6.1 & \pm & 0.19 & 6.0 & \pm & 0.45 & 6.0 & \pm & 0.16 \\
\hline & CD & & - & & & - & & & - & & & - & \\
\hline & F-value & & 0.52 & & & 0.15 & & & 1.87 & & & 1.0 & \\
\hline
\end{tabular}

With regard to the plasma inorganic phosphorus levels, the values varied nonsignificantly $(\mathrm{P} \geq 0.05)$ from as low as 5.6 $\left(\mathrm{T}_{2}\right)$ to as high as $5.9\left(\mathrm{~T}_{4}\right) \mathrm{mg} / \mathrm{dl}$ on $1^{\text {st }}$ day; from $5.9\left(\mathrm{~T}_{1}\right)$ to $6.1\left(\mathrm{~T}_{4}\right) \mathrm{mg} / \mathrm{dl}$ on $28^{\text {th }}$ day and from $6.0\left(\mathrm{~T}_{4}\right)$ to $7.0\left(\mathrm{~T}_{3}\right) \mathrm{mg} / \mathrm{dl}$ on $56^{\text {th }}$ day. Quite similar to calcium, highest values were recorded again in low energy low protein fed group $\left(\mathrm{T}_{4}\right)$ during initial stages of the experiment and also found gradual increase in concentration over a time period. The pooled mean values ranged nonsignificantly $(\mathrm{P} \geq 0.05)$ from $5.9\left(\mathrm{~T}_{2}\right)$ to 6.3 $\mathrm{mg} / \mathrm{dl}\left(\mathrm{T}_{3}\right)$.

Similar results were observed in an experiment supplemented with turmeric powder and ginger powder in broiler ration with no difference ( $\mathrm{P}>0.05)$ among serum calcium and phosphorus levels and concluded that supplementation is good (Sahoo et al., 2018). Likewise, one more study conducted to evaluate the effects of dietary supplementation with calcium varying in particle size and different calcium sources on blood calcium concentration with comparing vitamin $D_{3}$ supplementation in laying hens showed no significant influence on blood calcium concentration, however, there was a linear tendency to increase (Park et al., 2017).

A study in Chabro chicken on macro mineral content in blood was found within normal physiological range fed with different levels of azolla (Mishra et al., 2016). Likewise, Swarnadhara birds fed with reducing dietary crude protein levels supplemented with limiting amino acids in both chick as well as layer stage showed statistically similar $(\mathrm{P} \geq$ 0.05) serum calcium and inorganic phosphorus values (Beena et al., 2017; Beena, 2017). Since no published normal physiological values for the said minerals with respect to Swarnadhara strain at grower stage, analysed values were quite acceptable without any adverse effects and hence were considered to be present in the normal range.

In conclusion, selected levels of both energy as well as protein in this experiment have showed no deleterious effect on bird's health with respect to the blood biochemical profile. 


\section{References}

AOAC. 2005. Official methods of analysis. Association of Official Analytical Chemists. $18^{\text {th }}$ edition. Washington, D.C.

Beena, C.J. 2017. Effect of reducing crude protein levels supplemented with limiting amino acids on the performance of Swarnadhara female parent and its progeny. Ph.D. thesis submitted to Karnataka Veterinary, Animal and Fisheries Sciences University, Bidar.

Beena, C.J., Jayanaik and Rajeshwari, Y.B. 2017. Effect of Reduced Dietary Crude Protein with Balanced Limiting Amino Acids on Immunity and Serum Biochemical Profile of Swarnadhara Chicks. Int. J. Live. Res., 7(6), 38-44.

Calneck, B.W., Barnes, H.J., Beard, C.W., Reid W.M. and Yoder, H.W. 1992. Diseases of Poultry. $9^{\text {th }}$ edition. Wolf Publishing Ltd., USA.

Johri, T.S. and Shrivastava H.P. 2005. Paramount emphasis on poultry science education in India. In: Proc. of XXIII Indian Poultry Science Association Conference. 259-262.

Krishna Rao. 2002. Appropriate poultry strains of weaker sections - why and how? In: Souvenir of $2^{\text {nd }}$ National seminar on Rural Poultry for Adverse Environment. 15-21.

Mishra, D.B., Roy, D., Kumar, V., Bhattacharyya, A., Kumar, M., Kushwaha, R., Vaswani, S. 2016. Effect of feeding different levels of Azolla pinnata on blood biochemicals, hematology and immunocompetence traits of Chabro chicken, Vet. World., 9(2): 192198.

Park, J.H., Jeong, J.S., Lee, S.I. and Kim, I.H.
2017. Influence of dietary particle size and sources of calcium and vitamin D3 on production performance, egg quality, and blood calcium concentration of ISA brown laying hens. Anim. Nutr. Feed Technol., 17: $1-12$.

Poultry Trends. 2019. Watt Executive Guide to World. www.WATTAgNet.com. Acessed on 25.09.2019.

Reddy, B.S.V. and Rajendiran, A.S. 2002. Nutritional support for Giriraja under adverse environment. In: State level Seminar on "Giriraja bird - A boon for rural economy". AH \& VS, Government of Karnataka.

Sahoo, N., Mishra, S.K., Swain, R.K., Behura, N.C., Sethy, K., Pati, P.K., Sahoo, L., Samanta, G. and Debata, N.R. 2018. Comparative and combined effect of turmeric and ginger supplementation on growth, carcass characteristics, blood parameters and economics of productions in broiler birds. Anim. Nutr. Feed Technol., 18: 243-256.

Singh, D.P. 2005. Indigenous germplasm: Role in improving poultry production. In: Proc. of XXIII Indian Poultry Science Association Conference. Pp. 182-186.

Snedecor, G.W. and Cochran, W.G. 1989. Statistical Methods. $9^{\text {th }}$ edition. The Iowa State University Press, Ames, Iowa.

Veeranna, K. C. 2019. Rural women empowerment and entrepreneurship development through backyard poultry production: An Action Research. In: Proc. of the $7^{\text {th }}$ Pan Commonwealth Veterinary Conference. 339.

\section{How to cite this article:}

Suma, N., B. S. Venkatarami Reddy, S. Naveen Kumar, K. P. Chethan, G.U. Manju and Adarsh, J.. 2020. Blood Biochemical Profile of Swarnadhara Grower Parents as Influenced by Different Levels of Energy and Protein in the Diet. Int.J.Curr.Microbiol.App.Sci. 9(03): 570578. doi: https://doi.org/10.20546/ijcmas.2020.903.067 